NBER WORKING PAPER SERIES

\title{
THE EMPLOYMENT EFFECTS OF MINIMUM WAGES: SOME QUESTIONS WE NEED TO ANSWER
}

\author{
David Neumark \\ Working Paper 23584 \\ http://www.nber.org/papers/w23584 \\ NATIONAL BUREAU OF ECONOMIC RESEARCH \\ 1050 Massachusetts Avenue \\ Cambridge, MA 02138 \\ July 2017, Revised October 2017
}

I am grateful to William Wascher for helpful comments. The views expressed herein are those of the author and do not necessarily reflect the views of the National Bureau of Economic Research.

NBER working papers are circulated for discussion and comment purposes. They have not been peerreviewed or been subject to the review by the NBER Board of Directors that accompanies official NBER publications.

(C) 2017 by David Neumark. All rights reserved. Short sections of text, not to exceed two paragraphs, may be quoted without explicit permission provided that full credit, including $\odot$ notice, is given to the source. 
The Employment Effects of Minimum Wages: Some Questions We Need to Answer David Neumark

NBER Working Paper No. 23584

July 2017, Revised October 2017

JEL No. J23,J38

\begin{abstract}
$\underline{\text { ABSTRACT }}$
The literature on the employment effects of minimum wages is about a century old, and includes hundreds of studies. Yet the debate among researchers about the employment effects of minimum wages remains intense and unsettled. This essay discusses the key questions that have arisen in the past research that, if we can answer them, may prove most useful in making sense of the conflicting evidence. I also focus on additional questions we should consider to better inform the policy debate, in particular in the context of the very high minimum wages coming on line in the United States, about which past research is quite uninformative.
\end{abstract}

David Neumark

Department of Economics

University of California at Irvine

3151 Social Science Plaza

Irvine, CA 92697

and NBER

dneumark@uci.edu 


\section{The Employment Effects of Minimum Wages: Some Questions We Need to Answer}

David Neumark ${ }^{1}$

\section{Summary}

The literature on the employment effects of minimum wages is about a century old, and includes hundreds of studies. Yet the debate among researchers about the employment effects of minimum wages remains intense and unsettled. This essay discusses the key questions that have arisen in the past research that, if we can answer them, may prove most useful in making sense of the conflicting evidence. I also focus on additional questions we should consider to better inform the policy debate, in particular in the context of the very high minimum wages coming on line in the United States, about which past research is quite uninformative.

Keywords

minimum wage, employment effects, labor economics, econometrics, panel data, controls, trends

“[I]f you know what you believe, it makes it a lot easier to answer questions.”

George W. Bush

\section{Introduction}

The literature on the employment effects of minimum wages is about a century old, and includes hundreds of studies. Some of the very earliest studies followed the adoption of a state minimum wage in 1914 and a national minimum wage in the United States in 1938, using empirical techniques that are not too far removed from the difference-in-differences approaches still done today. ${ }^{2}$ Yet despite the scores of studies, the development of richer data, and the development of more-refined empirical techniques, the debate among researchers about the employment effects of minimum wages - and concerning not just the magnitude, but the broader question of whether a higher minimum wage reduces employment - remains intense and unsettled. $^{3}$

Research on the employment effects of minimum wages has already been synthesized and reviewed extensively. ${ }^{4}$ Thus, in this essay I do not attempt to summarize or augment these 
prior reviews. Rather, my purpose is to identify key research questions. I focus, in part, on the key questions that have arisen in the past research that, if we can answer them, may prove most useful in making sense of the conflicting evidence. I also focus on additional questions we should consider to better inform the policy debate, in particular in the context of the very high minimum wages coming on line in the United States, about which past research is quite uninformative. Thus, my focus is on the important questions to which we do not know the answer, rather than my views on what the prior research says about key questions in the minimum wage literature. ${ }^{5}$ As such, my goal is to provide what I view as the most promising suggestions and roadmap for future research on the employment effects of minimum wages. ${ }^{6}$

My review and discussion focuses on U.S. evidence. Of course, there is growing evidence on employment effects of minimum wages in other countries. But the U.S. experience has dominated the literature because of the availability of significant cross-state variation in minimum wages for nearly three decades, and the U.S. literature has by and large raised all of the important issues. Moreover, this essay is not meant to be an exhaustive review of the literature. ${ }^{7}$

Because I am trying to provide a roadmap for future research, I am also motivated to focus on the United States because the very large minimum wage increases already occurring or scheduled to occur soon, or likely to be enacted, in U.S. cities and states are likely to dominate both research and policy debate about minimum wages in the coming years. ${ }^{8}$ Thus, it is important to do more to ask what existing data can tell us about the likely employment effects of these increases, and to consider how we might expand what we know from past data as well as incorporate new data to exploit these large minimum wage increases to solidify our understanding of the employment effects of much higher minimum wages. Whatever one thinks of the merits of the coming minimum wage increases, they should afford an unparalleled 
opportunity to learn more about the effects of minimum wages on employment (and other outcomes).

Regardless of one's precise view of what the minimum wage literature on the whole says about the employment effects of minimum wages, it is clear that there is variation in the magnitude of estimated employment effects across studies. The debate is often characterized as being about whether the elasticity for low-skilled groups is equal to (or more precisely indistinguishable from) zero, or more likely in the range of -0.1 to -0.2 , although there are larger negative estimates in the literature (e.g., Clemens and Wither, 2014, and see Table 1 below), and occasional large positive estimates (most notably, Card and Krueger, 1994).

Most of the existing research that debates the findings of these studies focuses on econometric issues that may be responsible for the variation in effects across studies. However, remarkably little attention has been given to economic factors that may explain variation in estimated employment effects across studies. A sharper focus on these economic factors may be particularly important in the current and pending policy environment in the United States, because trying to predict the effects of large minimum wage increases from simple extrapolation of reduced-form estimates of the employment effects of minimum wages, based on evidence from much lower minimum levels and much more moderate changes, is a highly dubious exercise. In contrast, a better understanding of the factors underlying variation in minimum wage effects would likely enhance our ability to predict the effects of “out of sample” policy changes. Hence, in outlining what I view as promising avenues for future research I focus on both econometric issues and some issues of the underlying economics.

\section{Econometric Issues}


Regardless of what we can or will be able to say about larger minimum wage increases, we are still faced with contention over what the research evidence says about the employment effects of past smaller minimum wage increases. There are two key econometric issues that have been identified in recent research as underlying the different answers researchers have obtained. It seems natural, then, that further research on these econometric issues could prove productive in helping to resolve the debate.

First, like in any attempt to estimate causal effects of policy, it is critical to choose appropriate controls to provide a counterfactual for what would have happened absent the minimum wage increase. But this is not always easy. The standard two-way fixed effects model is a difference-in-differences (DD) estimator, comparing changes in low-skilled employment in states where the minimum wage increased more to states where it increased less (or not at all). However, recently Allegretto et al. (2011) and Dube et al. (2010) have raised the concern that cross-state policy variation is correlated with shocks that also affect outcomes. They report differences in estimates between panel data estimators in which all states could potentially serve as controls - which yield “conventional” negative elasticities - versus estimators using only geographically close areas as controls - which yield estimates closer to and statistically indistinguishable from zero. ${ }^{9}$ The idea motivating the use of "close controls" is that the states (or subareas of states) affected by minimum wage increases may experience the same economic shocks to low-skill labor markets as nearby areas unaffected by these increases, and thus more reliably identify the causal effects of minimum wages.

This work has spurred three kinds of responses. First, research has explored the validity of the controls used in this approach (Neumark et al., 2014a; Neumark and Wascher, 2017). ${ }^{10}$ Second, and closely related to this question, researchers have pushed further the development of 
econometric techniques to select and construct control areas (Powell, 2016; Totty, 2015), with Powell building on the synthetic control methods of Abadie et al. (2010). And third, a number of studies have adopted alternative identification strategies to isolate the effects of minimum wage increases from shocks that are potentially correlated with them.

In this latter category, the most natural extension is to use triple-differences (DDD) estimators that isolate the effect of the policy change by introducing another group exposed to the same shock but not the policy change - exactly the problem that motivates Allegretto et al. and Dube et al.

Thompson (2009) - which predates these two papers - uses a DDD approach based on differences in wage levels across counties within a state. This allows the inclusion of state-byperiod fixed effects, which control for state-specific shocks. Using variation generated by the federal increases in 1996 and 1997, Thompson finds large disemployment effects in counties where minimum wages are more binding because wages are lower and workers are lower skilled. Clemens and Wither (2014) focus on the 2007-2009 federal minimum wage increases, comparing changes in employment for the lowest-wage workers whose wages were differentially affected by the federal increases (because of prior variation in state minimum wages), to changes in employment for workers who earned wages that were low, but high enough that the federal minimum wage had little impact on them. They estimate a large employment elasticity for directly affected workers (of about -0.97 based on SIPP data). ${ }^{13}$

Baskaya and Rubinstein (2015) address the same problem of shocks correlated with state minimum wage increases. But they instead use instrumental variables (IV) to address the potential correlation of minimum wage changes with shocks to low-skill labor markets, in estimating the effects of minimum wage on teen employment. Their IV is the interaction 
between the federal minimum wage and a measure of the historical propensity for each state to let the federal minimum wage bind, which is intended to purge the estimated minimum wage effect of bias from states endogenously choosing their minimum wage in response to shocks to state-level economic conditions. Their IV elasticity estimates for teenagers are larger than many past estimates (and their OLS estimates), in the range -0.3 to -0.5 . Their finding that the IV estimates are larger than the OLS estimates is consistent with policymakers raising minimum wages when youth labor market conditions are strong (in contrast to the direction of bias implied by the results from the close-controls approach).

Thus, across these and related studies, a puzzle emerges. Studies using close controls generally find very small disemployment effects usually indistinguishable from zero. But other identification strategies - DDD estimators that control for state-specific shocks, IV estimates that purge the minimum wage variable of correlation with these shocks, as well as the most advanced synthetic control estimator (Powell, 2016) - tend to find larger disemployment effects. Results across many recent studies - including those discussed above - are summarized in Table 1.

[Insert Table 1 here]

There is therefore, clearly, an important research challenge and question of figuring out why the different strategies generate different results, and trying to determine which strategy or strategies is most reliable. One possibility raised by Neumark and Wascher (2014b) is that minimum wage increases within similar geographic areas are actually more endogenous with respect to economic shocks, as other factors that differ more substantially between states in different regions, and that provide exogenous variation - such as unionization or politics - play less of role for close controls, implying that differences in economic conditions between treatment states and close controls, even if smaller, may matter more for determining minimum 
wages. However, it is clear that additional work is needed to resolve this question.

Another issue that has been highlighted recent work - which bears some relation to the construction of the counterfactual but not in as transparent a way - is the sensitivity of estimated employment effects to the inclusion of state-specific time trends. ${ }^{15}$ In panel data analyses of policy effects (based on DD estimation), it is quite standard to include linear time trends specific to the states (or other jurisdictions) under study. This can be seen as correcting for violations of the "parallel trends" assumption, by controlling for cross-state differences in the evolution of outcomes both before and after minimum wage increases. The concern is of course valid. My sense, though, is that the evidence on minimum wage effects on employment is far more sensitive to this robustness check than in many other areas of research. The question arises, then: How do we interpret the findings when the results are not robust?

There are well-known problems in applying this approach, in particular when the pretreatment periods are short, because the identification of trends includes the post-treatment period and hence can be hard to distinguish from actual policy effects. I am not aware of definitive ways to avoid this problem and more reliably separate the effects of policy from the trends, but it is an important question. Moreover, it can be hard to characterize the counterfactual in a clear way when these trends are included. Meer and West (2016) demonstrate this quite clearly in the context of estimating effects of minimum wages on employment growth. ${ }^{18}$ The question remains, though, of what we should conclude when estimates are quite sensitive to the inclusion of state-specific linear trends. It is clear to me that the estimates including these trends are not necessarily the best ones. But how we get further than that is an open question. One potentially interesting approach is taken in Monras (2015), who allows for separate trends pre- and post-treatment, in an event-study design. One might also 
want to try to estimate the trends only from the pre-treatment period, and then use these to detrend the post-treatment data, to avoid confounding policy effects and estimation of trends. However, this gets problematic without long pre-treatment periods before minimum wage increase "events." In this vein, one additional advantage of the DDD estimators discussed above (as well as synthetic control matching) is that they obviate the need to include state-specific trends - since each state can have an arbitrary pattern of time effects - thus sidestepping this issue.

Finally, it is important to recognize that evidence that estimates are sensitive to the inclusion of trends is, ultimately, a sign of our ignorance. The appeal to including trends is typically based on the hypothesized influence of omitted variables that underlie these trends. ${ }^{19}$ This suggests that more compelling evidence will come from expanding the variables used in minimum wage studies to include the hypothesized omitted variables. Indeed, at least in the literature using aggregated data, most employment equation specifications in the literature are quite parsimonious, often including only an aggregate labor market indicator and a relative supply variable (like the share of the young population in the total population), in addition to state and year (or other) fixed effects (plus perhaps the trends). This is rather striking relative to research on other topics where a much more extensive list of controls is typically included. There is merit, of course, in replicating results using specifications utilized in earlier work. But the sensitivity of estimates to the inclusion of trends suggests that there may be a good deal to be learned from instead including the omitted controls that we think might affect low-skilled employment and be correlated with minimum wages.

\section{Economic Factors}


In addition to these econometric issues that may help us sort out the past research and inform future research, there are a number of economic factors that have received relatively little attention as potential sources of variation in estimated employment effects across studies. Additional research on the influence of these economic factors on the employment effects of minimum wages will also likely prove useful in better understanding the effects of much larger minimum wage increases.

Perhaps the economic factor of most importance in thinking about the effects of much higher minimum wages, but one that may inform the literature more generally, is the question of how the "bite" of the minimum wage - i.e., how much the minimum wage binds - affects the estimated employment effects of the minimum wage. This question has received a bit of attention in the literature, but my sense is that there is considerable scope for progress.

One indirect approach to this question is an earlier study by Castillo-Freeman and Freeman (1992), who estimated the effects of the minimum wage in Puerto Rico, a U.S. territory that is bound by the U.S. minimum wage but has much lower wage levels, and hence where the minimum wage has much more bite. They reported very large aggregate employment effects and particularly adverse effects on low-wage industries, consistent with stronger disemployment effects where the minimum wage binds strongly. This evidence was revisited by Krueger (1995), who found evidence of disemployment effects from time-series data but not crossindustry analyses, and concluded that evidence of disemployment effects was fragile. But, surprisingly, to the best of my knowledge the evidence on Puerto Rico has not been revisited. Of course, evidence for one jurisdiction suffers from the absence of a control group - the same concern regarding the earlier time-series evidence for the United States that fueled the interest in 
minimum wage research using across-state variation in state minimum wages that emerged in the late 1980s (and which motivated the cross-industry analysis in the two Puerto Rico studies).

A more general approach is taken in Neumark and Wascher (2002). This study adopts techniques from the earlier market disequilibrium literature (applied to labor markets in, e.g., Rosen and Quandt, 1978). The paper specifies a labor demand and labor supply curve, and fits a model that estimates the parameters of these curves as well as the probability that an observation is on the demand curve (the short side of the market when, in the standard model, the minimum wage is set too high), or instead at market equilibrium. The estimates of this model were used to compute these probabilities for minimum wages studied in other research, asking, in particular, whether some studies finding no effect of the minimum wage (in particular, Card 1992a, 1992b) were likely using minimum wage variation in the range where the minimum wage was not binding. ${ }^{20}$ This approach relies heavily on structural assumptions. But it can provide some insight into the likely effects of much higher minimum wages at least in terms of estimating the probability that a minimum wage at a given level is likely to be binding.

However, the approach in Neumark and Wascher (2002) is based on a market for homogeneous labor, and as such misses what is likely the key issue with regard to much higher minimum wages - how the effect changes as the share of workers affected increases. On this score, the most relevant approach may be that used by Card (1992a) in one of the first papers in the new minimum wage research that emerged in the early 1990s using state minimum wage variation. Card specified the minimum wage variable as the fraction affected by given minimum wage increases, rather than the minimum wage level or its ratio relative to a measure of mean or median wages (often called, not quite accurately, the "Kaitz index"). ${ }^{21}$ This approach is, potentially, more directly useful for projecting the effects of much higher minimum wages, so it 
may be useful for studies of the employment effects of minimum wages to go back to this kind of specification. However, Baskaya and Rubinstein (2015) suggest that this kind of fraction affected variable is particularly prone to endogeneity with respect to local labor market shocks, and is procyclical and hence leads to bias against finding a disemployment effect. Thus, incorporation of measures of the bindingness of minimum wages may not be straightforward.

A different perspective on the bite of the minimum wage that has been explored in recent work is not only how high the minimum wage is relative to the wage distribution, but for how long firms expect a minimum wage increase to alter their costs. This issue has been highlighted by Sorkin (2015), who notes that firms may have reasonably expected the kind of non-indexed, often infrequent minimum wage increases enacted in the United States to be offset by rising nominal wages (and prices) over time, which reduces the incentive for firms to invest in alternative production technologies that economize on low-skilled labor. ${ }^{22}$ In contrast, indexed minimum wages, which are becoming increasingly common in U.S. states, ${ }^{23}$ may well generate more adverse longer-run employment effects for low-skilled workers - a question that has not yet been explored much (although see Allegretto et al., 2011). Much larger minimum wage increases, especially in a low-inflation environment, also seem likely to be perceived by firms as creating longer-term (if not permanent) relative increases in the cost of low-skilled labor.

Of course, when the variation likely to be induced by very high minimum wages is well outside the range of sample variation, the "fraction-affected" approach (putting aside endogeneity concerns) is also unreliable. However, in very recent years, variation in minimum wages across states has become sufficiently strong that it should be possible, using recent data, to start to obtain more reliable estimates of the effects of minimum wages that bind for a much larger share of workers. It might also be promising to extrapolate results from groups of workers 
with a high fraction affected to groups with a lower fraction affected, if we believe that aside from how binding the minimum wage is, labor demand responses are likely to be similar across these groups. Still, the higher minimum wages have been applied in higher-wage states, leaving extrapolation to lower-wage states problematic. (See Figure 1.)

[Insert Figure 1 here]

There may be value in considering more structural approaches, whether using estimated or, as in the case of Reich et al. (2015), calibrated models. The problem, of course, is that the evidence on past minimum wage increases needed to calibrate the model is contested. ${ }^{24}$ It would therefore surely be useful to gauge the sensitivity of these kinds of exercises to calibrations that reflect the larger employment elasticities that many recent studies find, ${ }^{27}$ and perhaps even more useful to push this approach further, including estimation of structural models that could at least provide complementary evidence on predicted effects of out-of-sample minimum wage increases.

Closely related to the question of the bite of the minimum wage is the extent to which studies identify the effects of minimum wages on affected workers. Neumark and Wascher (2007), in their narrative review of minimum wage research on employment effects since the early 1990s, argued that studies that focused on the least-skilled workers tended to find the sharpest evidence of disemployment effects. However, this argument was based on, in some sense, a qualitative assessment of the evidence across studies, rather than systematic empirical evidence comparing studies.

The most common group considered in studies of the employment effects of minimum wages is teenagers. This is a logical group to study, as teenagers generally earn very low wages because of their low skills, and represent a vastly disproportionate share of minimum wage 
workers. ${ }^{28}$ Moreover, the focus on teens is to some extent a holdover from the earlier time-series literature that used aggregate employment rates that were reported for different age groups (Brown et al., 1982). ${ }^{29}$

The earlier constraints posed by the available time-series data are no longer binding, and with the micro-data now available to labor economists, it is possible to focus directly on workers affected by the minimum wage. Examples of minimum wage studies that try to identify impacts on affected workers, based on their wages, include Neumark et al. (2004) and, more recently, Clemens and Wither (2014). There is, however, an important limitation of such an approach. We can observe those currently working and whether their wages are low (say, below some threshold just above the minimum wage). We can then estimate the effects of minimum wage increases on the likelihood that these affected low-wage workers remain employed. However, such evidence misses the effects of minimum wages on transitions from non-employment to employment, which, for low-skill workers bound by the minimum wage, could become less frequent.

Changes in the rate of entry into employment, however, could be a quite important channel of employment adjustments. First, low-skill workers have very high turnover. ${ }^{30}$ Second, there is evidence from data on worker flows that minimum wages lower the rate at which workers separate from firms and also lower the rate at which workers are hired (Dube et al., 2016; Gittings and Schmutte, 2016). ${ }^{31}$ Thus, ignoring the effects of minimum wages in reducing the flows of workers into jobs may well miss a potentially important means by which higher minimum wages reduce employment of low-skilled workers. Of course, standard employment analyses of low-skill groups, such as teenagers, can help provide a fuller picture. Research that more directly estimates the effects of minimum wages on affected workers is 
important. For example, we may find that estimated employment effects are more common across studies when attention focuses on directly affected workers, and that that differences in results across studies are partly attributable to differences in the share affected - comparing, for example, studies of teenagers versus restaurant workers, or studies across periods in which the difference between the minimum wage and the equilibrium wage for low-skilled workers varies. Moreover, it may give us a better handle on predicting effects of much higher minimum wages that will affect more workers. ${ }^{32}$ But our ignorance of likely offer wages for non-employed workers poses a serious challenge. Selection-type models that predict wages for the low-skilled, non-employed could in principle be used, although given the relatively low explanatory power of wage regressions, it seems unlikely that such methods would accurately identify the lowest-wage workers. Longer-term panel data can tell us something about wages workers earned on previous jobs, which could potentially prove useful, although that information, too, may be available only for a subset of currently non-employed workers.

I view this as a critical challenge. At a minimum, labor economists should be using the available micro-data to try to identify skill and demographic groups likely to be affected by minimum wages, moving beyond just teenagers or workers in low-wage industries. ${ }^{33}$ But it may prove more useful to think about how to use panel data with wage information, or other methods, to directly identify workers and non-workers most affected by higher minimum wages and how minimum wage increases affect their flows into and out of employment. One potentially largescale source of data that could be used is Unemployment Insurance records for the subset of states that report quarterly hours as well as earnings, from which wages can then be estimated conditional on states making the data available to researchers, like in the recent study of the Seattle minimum wage. ${ }^{34}$ 
In addition to potentially explaining variation in effects across studies, empirical research providing a tighter link between workers affected by the minimum wage and the employment effects they experience can sharpen our understanding of the policy implications of higher minimum wages. Minimum wage-employment elasticities for teenagers, for example, are often characterized as “small” or “modest.” Although this is a vague characterization, I believe what most economists mean by this characterization is that because estimated employment elasticities in the range -.1 to -.2 are well below 1 in absolute value, the earnings of affected workers, on the whole, will rise substantially when the minimum wage is raised (e.g., Freeman, 1996).

But the fact that the existing research does not focus solely on affected workers means that the relevant elasticity for asking how minimum wages influence the incomes of affected workers must be larger in absolute value. For example, we can write the minimum wage elasticity estimated for all teenagers (the most common type of estimate) as a weighted average of the elasticity for teenagers directly affected by a change in the minimum wage and the elasticity for teenagers currently earning above the minimum wage, or:

$$
e=e^{A} \cdot p^{A}+e^{N A} \cdot\left(1-p^{A}\right)
$$

where $e$ is the estimated elasticity for teenagers as a whole, $e^{A}$ and $e^{N A}$ are the minimum wage elasticities for affected and unaffected teens, and $p^{A}$ is the proportion directly affected by the change in the minimum wage. If we simplify and assume that the elasticity for unaffected workers is zero, then the minimum wage elasticity for affected teens $\left(e^{A}\right)$ can be written:

$$
e^{A}=e / p^{A}
$$

It follows that the minimum wage elasticity for affected teenage workers is greater than the elasticity estimated for teenagers as a whole. 
Naturally, the smaller the share of affected workers in the group studied, the less reflective is the estimated employment elasticity of the actual impact on affected workers. Thus, directly identifying the employment effect of minimum wages for affected workers would give us a more accurate sense of how minimum wage increases influence the earnings of the lowestskill workers who are the intended "targets" of a minimum wage increase. ${ }^{35}$

Another economic factor that can potentially help us pin down sources of variation in minimum wage effects across studies is labor-labor substitution. In a model with workers of different skill levels, a minimum wage that is binding for some workers is likely to generate some substitution towards higher-skill workers. One implication is that evidence on the employment effects of minimum wages that combine negative employment effects for the leastskilled with positive employment effects for those who benefit from labor-labor substitution will understate the net effects on the first group. A second implication is that such evidence will obscure the positive impacts on those workers who benefit from labor-labor substitution. There is some evidence of labor-labor substitution, from research on both minimum wages (Neumark and Wascher, 2003) and on living wages (Fairris and Bujunda, 2008). ${ }^{36}$ But there is virtually no research that tries to use information on workers across a larger swath of the skill distribution to provide a fuller accounting of who gains and who loses from a higher minimum wage.

Note, also, that this kind of evidence on how minimum wages affect workers at different parts of the skill distribution - including both direct estimation of the effects of minimum wages on the least-skilled workers, as well as labor-labor substitution - is also likely to be informative about the effects of much higher minimum wages. Presumably, the ability to substitute away from labor whose price is directly increased by the minimum wage is diminished as the minimum wage affects the wages of a larger share of workers. 
Another issue that arises in thinking about the effects of minimum wages on workers above the minimum wage is the extent to which wages of higher-skilled workers might be affected by constraints on pay that require a wage gradient between the lowest-skilled workers and those with somewhat higher skill or experience - a phenomenon first identified as "ripple" effects (Grossman, 1983). Labor economists have studied directly how minimum wages affect the wage distribution, mainly with this question in mind (e.g., Autor et al., 2016). ${ }^{37}$ In general, the evidence for such effects suggests that they are somewhat limited. Still, there are two important questions. First, do the wage effects above the minimum wage reflect labor-labor substitution, implying that workers above the minimum experience both higher wages and higher employment, or do they instead reflect relative wage constraints, in which case employment of such workers might fall, with more ambiguous implications for somewhat higher-wage workers? And second, how might these effects change with much higher minimum wages that would otherwise flatten wages over larger range of firms’ wage distributions?

Finally, spurred in part by the existence of studies that do not find evidence of disemployment effects of minimum wages, and occasionally even find positive effects, minimum wage researchers have sometimes appealed to monopsony search models as a better characterization of the low-skill labor market (beginning with Card and Krueger, 1995, and developed to a much greater extent in Manning, 2005). Understanding the underlying model is obviously central to identifying economic factors that can explain variation in the employment effects of minimum wages across studies.

Search models can, indeed, predict a positive effect of minimum wages over some range. This was first pointed out in Stigler (1946), albeit in the case of a textbook single-buyer monopsony model. Brown et al. (2014) show in a fairly simple way how this result emerges in a 
modern search model that instead generates rising marginal costs of labor from frictions. It is possible that search-monopsony models can account for the variation in estimated employment effects of minimum wages across studies.

However, establishing that search-monopsony models can account for the variation in estimated employment effects across studies requires much more than noting that these models are consistent with such variation. As I have emphasized above, there are many reasons to expect variation in employment effects when the neoclassical model characterizes low-skill labor markets. I would find more convincing the claim that monopsony models can account for the variation in estimates - and therefore also the implication that minimum wages can sometimes increase employment - if there were evidence that directly tied variation in minimum wage effects to the predictions of these models. Christl et al. (forthcoming) report evidence of a nonlinear minimum wage effect - first increasing and then decreasing - which is potentially consistent with these models. But evidence on more direct implications of these models would be more compelling. In particular, can we find evidence that the studies that find zero or even positive effects do this in settings where monopsony search models predict positive effects, and similarly find negative effects when the models predict negative effects - based, perhaps, on variation in the extent of frictions, in the level of the minimum wage, in the time frame (shortversus longer-run), etc.? $?^{38}$

Of course, by the same token, the neoclassical model should not simply be taken as the default in the absence of more compelling evidence that the search-monopsony models can explain the variation in employment effects across studies. In line with much of the discussion above, the neoclassical characterization of low-skill labor markets would be enhanced by more 
convincing evidence that variation across studies in estimated employment effects can be explained in the context of this model.

\section{How Do We Synthesize a Large and Conflicting Literature?}

With the accumulation of sometimes conflicting evidence on the employment effects of minimum wages, one question that comes to the fore is how we try to draw conclusions from this large literature. ${ }^{39}$ Neumark and Wascher (2007) used a narrative review of an extensive set of papers, attempting to draw conclusions about what factors explain variation in estimated effects, as well as providing an assessment - admittedly subjective - of which studies were most reliable. An advantage of this approach - in particular the assessment - is that it can weight more heavily the more reliable studies. There are, however, two disadvantages. First, researchers can have different views of the reliability of different studies. And second, the conclusions drawn about what study characteristics explain variation in estimated employment effects are not based on systematic empirical analysis.

An alternative approach is meta-analysis, which can summarize a literature by essentially averaging estimates across studies, possibly weighted, and can also provide more systematic evidence on what study factors explain variation in estimated employment effects (Doucouliagos and Stanley, 2009; Belman and Wolfson, 2014). ${ }^{40}$ However, averaging estimates from studies of minimum wage effects, as meta-analyses do, is problematic. First - as discussed in more detail above - the population studied often varies, and this and other factors can influence how binding the minimum wage is, generating variation in estimated effects that there is no reason to simply average.

A more fundamental problem, in my view, is the failure to account for more reliable versus less reliable studies. In fact, it may be worse than this. Meta-analyses often assign more 
weight to estimates that are more statistically precise (e.g., Belman and Wolfson, 2014), even though the most rigorous empirical methods are likely to be less precise. Yet it is precisely the studies using the most rigorous methods - if valid - that that should receive the most weight - if not all the weight. Moreover, if we think the studies using less-rigorous methods (e.g., failing to instrument for an endogenous policy, or using a less-saturated model that does not account for some sources of heterogeneity bias) lead to biased estimates, we should not incorporate these studies at all in "aggregating” across the research literature. ${ }^{42}$

My sense is that the implication of these issues is that the meta-analysis approach to synthesizing the literature on the employment effects of minimum wages is likely uninformative. But there may be a way to use these types of analyses to provide more definitive results perhaps focusing more on why results differ across studies than on arriving at a single summary estimate. $^{43}$

\section{Conclusions}

Given all the research that has come before, how can researchers refine their understanding of the employment effects of minimum wages, and perhaps achieve (some) convergence of views? Although meta-analyses offer the hope of providing summary evidence, there are significant and perhaps insurmountable challenges to existing meta-analyses of studies of the employment effects of minimum wages. That is unfortunate, since it would, of course, be very helpful if there were fairly straightforward ways to empirically summarize a large research literature. But with such a large number of issues outstanding regarding how we should estimate minimum wage effects, and how they might vary based on other economic factors, I think a more fruitful approach is to identify and study what are likely (or plausibly) the central sources of differences in results, in the hope that this will narrow our range of estimates for studies focused 
on the same types of workers facing similar minimum wage increases, and enrich our understanding of why employment effects differ across workers, minimum wage levels, and perhaps other features of the labor market. ${ }^{44}$ Although not as alluring, perhaps, I think the progress that needs to be made will come from additional studies sorting out the best way to identify minimum wage effects on employment, which includes understanding why different approaches yield different answers, and from doing a good deal more than the existing research to recognize that there is not one minimum wage effect, and instead trying to better understand why the employment effects of minimum wages vary across workers, labor markets, time, and the policy environment. 


\section{References}

Aaronson, Daniel, Eric French, Isaac Sorkin, and Ted To. "Industry Dynamics and the Minimum Wage: A Putty-Clay Approach.” Forthcoming in International Economic Review.

Abadie, Alberto, Alexis Diamond, and Jens Hainmueller. 2010. "Synthetic Control Methods for Comparative Case Studies: Estimating the Effect of California's Tobacco Control Program.” Journal of the American Statistical Association, Vol. 105, No. 490, February, pp. 493-505.

Addison, John T., McKinley L. Blackburn, and Chad D. Cotti. 2013. “Minimum Wage Increases in a Recessionary Environment.” Labour Economics, Vol. 23, August, pp. 30-9.

Addison, John T., and Orgul Demet Ozturk. 2012. "Minimum Wages, Labor Market Institutions, and Female Employment: A Cross-Country Analysis.” Industrial and Labor Relations Review, Vol. 65, No. 4, pp. 779-809.

Allegretto, Sylvia A., Arindrajit Dube, and Michael Reich. 2011. “Do Minimum Wages Really Reduce Teen Employment? Accounting for Heterogeneity and Selectivity in State Panel Data.” Industrial Relations, Vol. 50, No. 2, April, pp. 205-40.

Allegretto, Sylvia A., Arindrajit Dube, Michael Reich, and Ben Zipperer. 2017. "Credible Research Designs for Minimum Wage Studies.” Industrial and Labor Relations Review, Vol. 70, No. 3, May, pp. 559-92.

Ashenfelter, Orley, Colm Harmon, and Hessel Oosterbeek. 1999. "A Review of Estimates of the Schooling/Earnings Relationship, with Tests for Publication Bias.” Labour Economics, Vol. 6, No. 4, November, pp. 453-70.

Autor, David H., Alan Manning, and Christopher L. Smith. 2016. “The Contribution of the Minimum Wage to U.S. Wage Inequality over Three Decades: A Reassessment.” American Economic Journal: Applied Economics, Vol. 8, No. 1, January, pp. 58-99.

Baskaya, Yusuf Soner, and Yona Rubinstein. 2015. "Using Federal Minimum Wages to Identify the Impact of Minimum Wages on Employment and Earnings across U.S. States.” Unpublished paper.

Belman, Dale, and Paul J. Wolfson. 2014. What Does the Minimum Wage Do? Kalamazoo, MI: Upjohn Institute.

Brown, Charles, Curtis Gilroy, and Andrew Kohen. 1982. "The Effect of the Minimum Wage on Employment and Unemployment.” Journal of Economic Literature, Vol. 20, No. 2, June, pp. 487-528.

Brown, Alessio. J. G., Christian Merkl, and Dennis J. Snower. 2014. "The Minimum Wage from a Two-Sided Perspective.” Economics Letters, Vol. 124, pp. 389-91.

Card, David. 1992a. "Using Regional Variation in Wages to Measure the Effects of the Federal Minimum Wage.” Industrial and Labor Relations Review, Vol. 46, No. 1, October, pp. 22-37.

Card, David. 1992b. "Do Minimum Wages Reduce Employment? A Case Study of California, 1987-1989.” Industrial and Labor Relations Review, Vol. 46, No. 1, October, pp. 38-54.

Card, David, and Alan B. Krueger. 1995. Myth and Measurement: The New Economics of the Minimum Wage. Princeton, N.J.: Princeton University Press.

Card, David, and Alan B. Krueger. 1994. "Minimum Wages and Employment: A Case Study of the Fast-Food Industry in New Jersey and Pennsylvania." American Economic Review, Vol. 84, No. 4, September, pp. 772-93.

Castillo-Freeman, Alida, and Richard B. Freeman. 1992. "When the Minimum Wage Really Bites: The Effect of the U.S.-Level Minimum on Puerto Rico.” In George. J. Borjas and 
Richard B. Freeman, Eds., Immigration and the Workforce: Economic Consequences for the United States and Source Areas. Chicago, IL: University of Chicago Press, pp. 177211.

Choi, Sekyu, and Fernández-Blanco, Javier. 2016. “A Note on U.S. Turnover.” Unpublished paper.

Christl, Michael, Monika Köppl-Turnya, and Dénes Kucsera. "Revisiting the Employment Effects of Minimum Wages in Europe.” Forthcoming in German Economic Review.

Clemens, Jeffrey, and Michael Wither. 2014. "The Minimum Wage and the Great Recession: Evidence of Effects on the Employment and Income Trajectories of Low-Skilled Workers.” NBER Working Paper No. 20724.

Doucouliagos, Hristos and T. D. Stanley. 2009. "Publication Selection Bias in Minimum-Wage Research? A Meta-Regression Analysis.” British Journal of Industrial Relations, Vol. 47, No. 2, June, pp. 406-28.

Douty, H. M. 1941. "Minimum Wage Regulation in the Seamless Hosiery Industry." Southern Economic Journal, Vol. 8, No. 2, October, pp. 176-90.

Dube, Arindrajit, T. William Lester, and Michael Reich. 2016. "Minimum Wage Shocks, Employment Flows, and Labor Market Frictions.” Journal of Labor Economics, Vol. 34, No. 3, July, pp. 663-704.

Dube, Arindrajit, T. William Lester, and Michael Reich. 2010. "Minimum Wage Effects across State Borders: Estimates Using Contiguous Counties.” Review of Economics and Statistics, Vol. 92, No. 4, November, pp. 945-64.

Dube, Arindrajit., and Ben Zipperer. 2015. "Pooling Multiple Case Studies using Synthetic Controls: An Application to Minimum Wage Policies.” IZA Discussion Paper No. 8944.

Fairris, David, and Leon Fernandez Bujunda. 2008. "The Dissipation of Minimum Wage Gains for Workers through Labor-Labor Substitution: Evidence from the Los Angeles Living Wage Ordinance.” Southern Economic Journal, Vol. 75, No. 2, October, pp. 473-96.

Freeman, Richard B. 1996. “The Minimum Wage as a Redistributive Tool.” Economic Journal, Vol. 106, No. 436, May, pp. 639-49.

Gittings, R. Kaj, and Ian M. Schmutte. 2016. "Getting Handcuffs on an Octopus: Minimum Wages, Employment, and Turnover.” Industrial and Labor Relations Review, Vol. 69, No. 5, October, pp. 1133-70.

Grossman, Jean Baldwin. 1983. “The Impact of the Minimum Wage on Other Wages.” Journal of Human Resources, Vol. 18, No. 3, Summer, pp. 359-78.

Hinrichs, A. F. 1940. "Effects of the 25-Cent Minimum Wage on Employment in the Seamless Hosiery Industry.” Journal of the American Statistical Association, Vol. 35, No. 209, March, pp. 13-23.

Jardim, Ekaterina, Mark C. Long, Robert Plotnick, Emma van Inwegen, Jacob Vigdor, and Hilary Wething. 2017. "Minimum Wage Increases, Wages, and Low-Wage Employment: Evidence from Seattle.” NBER Working Paper No. 23532.

Kaitz, Hyman. 1970. "Experience of the Past: The National Minimum.” Youth Unemployment and Minimum Wages. Bulletin 1657, U.S. Department of Labor, Bureau of Labor Statistics, pp. 30-54.

Kreiner, Claus T., Daniel Reck, and Peer E. Skov. 2017. “Do Lower Minimum Wages for Young Workers Raise their Employment? Evidence from a Danish Discontinuity.” Unpublished paper. 
Krueger, Alan B. 1995. "The Effect of the Minimum Wage When It Really Bites: A

Reexamination of the Evidence from Puerto Rico.” Research in Labor Economics, Vol. 14, pp. 1-22.

Liu, Shanshan, Thomas J. Hyclak, and Krishna Regmi. 2016. "Impact of the Minimum Wage on Youth Labor Markets.” LABOUR, Vol. 30, No. 1, March, pp. 18-37.

Manning, Alan. 2005. Monopsony in Motion. Princeton, NJ: Princeton University Press.

Meer, Jonathan, and Jeremy West. 2016 "Effects of the Minimum Wage on Employment Dynamics.” Journal of Human Resources, Vol. 51, No. 2, pp. 500-22.

Moloney, John F. 1942. "Some Effects of the Federal Fair Labor Standards Act Upon Southern Industry.” Southern Economic Journal, Vol. 9, No. 1, July, pp. 15-23.

Monras Joan. 2015. “Minimum Wages and Spatial Equilibrium: Theory and Evidence.” IZA Discussion Paper No. 9460.

Neumark, David. 2016. "Policy Levers to Increase Jobs and Increase Income from Work after the Great Recession.” IZA Journal of Labor Policy, 5:6 (on-line).

Neumark, David, J.M. Ian Salas, and William Wascher. 2014a. "Revisiting the Minimum WageEmployment Debate: Throwing out the Baby with the Bathwater?” Industrial and Labor Relations Review, Vol. 67, Supplement, pp. 608-48.

Neumark, David, J.M. Ian Salas, and William Wascher. 2014b. "More on Recent Evidence on the Effects of Minimum Wages in the United States.” IZA Journal of Labor Policy, 3:24 (on-line).

Neumark, David, Mark Schweitzer, and William Wascher. 2004. "Minimum Wage Effects Throughout the Wage Distribution.” Journal of Human Resources, Vol. 39, No. 2, Spring, pp. 425-50.

Neumark, David, Matthew Thompson, and Leslie Koyle. 2012. "The Effects of Living Wage Laws on Low-Wage Workers and Low-Income Families: What Do We Know Now?” IZA Journal of Labor Policy, 1:11 (on-line).

Neumark, David, and William Wascher. 2017. "Reply to Credible Research Designs for Minimum Wage Studies.” Industrial and Labor Relations Review, Vol. 70, No. 3, May, pp. 593-609.

Neumark, David, and William Wascher. 2008. Minimum Wages. Cambridge, MA: MIT Press.

Neumark, David, and William L. Wascher. 2007. "Minimum Wages and Employment.” Foundations and Trends in Microeconomics, Vol. 3, Nos. 1-2, pp. 1-182.

Neumark, David, and William Wascher. 2004. "Minimum Wages, Labor Market Institutions, and Youth Employment: A Cross-National Analysis.” Industrial and Labor Relations Review, Vol. 57, No. 2, pp. 223-48.

Neumark, David, and William Wascher. 2003. "Minimum Wages and Skill Acquisition." Economics of Education Review, Vol. 22, No. 1, February, pp. 1-10.

Neumark, David, and William Wascher. 2002. "State-Level Estimates of Minimum Wage Effects: New Evidence and Interpretations from Disequilibrium Methods.” Journal of Human Resources, Vol. 37, No. 1, Winter, pp. 35-62.

Obenauer, Marie L., and Bertha von der Nienburg. 1915. "Effect of Minimum-Wage Determination in Oregon.” Bureau of Labor Statistics Bulletin No. 176, United States Department of Labor, Washington, D.C.

Powell, David. 2016. “Synthetic Control Estimation Beyond Case Studies: Does the Minimum Wage Reduce Employment?” RAND Labor \& Population Working Paper WR-1142.

Reich, Michael, Ken Jacobs, Annette Bernhardt, and Ian Perry. 2015. “The Proposed Minimum 
Wage Law for Los Angeles: Economic Impact and Policy Outcomes.” Center on Wage and Employment Dynamics Policy Brief, University of California, Berkeley.

Reich, Michael, Claire Montialoux, Sylvia Allegretto, Ken Jacobs, Annette Bernhardt, and Sarah Thomason. 2016. “The Effects of a \$15 Minimum Wage by 2019 in San Jose and Santa Clara County.” Center on Wage and Employment Dynamics Policy Brief, University of California, Berkeley.

Rosen, Harvey S., and Richard E. Quandt. 1978. "Estimation of a Disequilibrium Aggregate Labor Market.” Review of Economics and Statistics, Vol. 60, No. 3, August, pp. 371-9.

Shirley, Peter. 2017. "The Effects of the Minimum Wage on Employment: Evidence from a Hierarchical Bayes Framework.” Unpublished paper.

Slichter, David. 2016. "The Employment Effects of the Minimum Wage: A Selection Ratio Approach to Measuring Treatment Effects.” Unpublished paper.

Sorkin, Isaac. 2015. “Are There Long-Run Effects of the Minimum Wage?” Review of Economic Dynamics, Vol. 18, No. 2, April, pp. 306-33.

Stigler, George J. 1946. “The Economics of Minimum Wage Legislation.” American Economic Review, Vol. 36, No. 3, June, pp. 358-65.

Thompson, Jeffrey P. 2009. "Using Local Labor Market Data to Re-examine the Employment Effects of the Minimum Wage.” Industrial and Labor Relations Review, Vol. 62, No. 3, April, pp. 343-66.

Totty, Evan. 2015. “The Effect of Minimum Wages on Employment: A Factor Model Approach.” Institute for Research on Labor and Employment Working Paper \#110-15.

Yannelis, Constantine. 2014. “The Minimum Wage and Employment Dynamics: Evidence from an Age Based Reform in Greece.” Unpublished paper. 
Figure 1: Percent Differences between State and Federal Minimum Wages, 2017

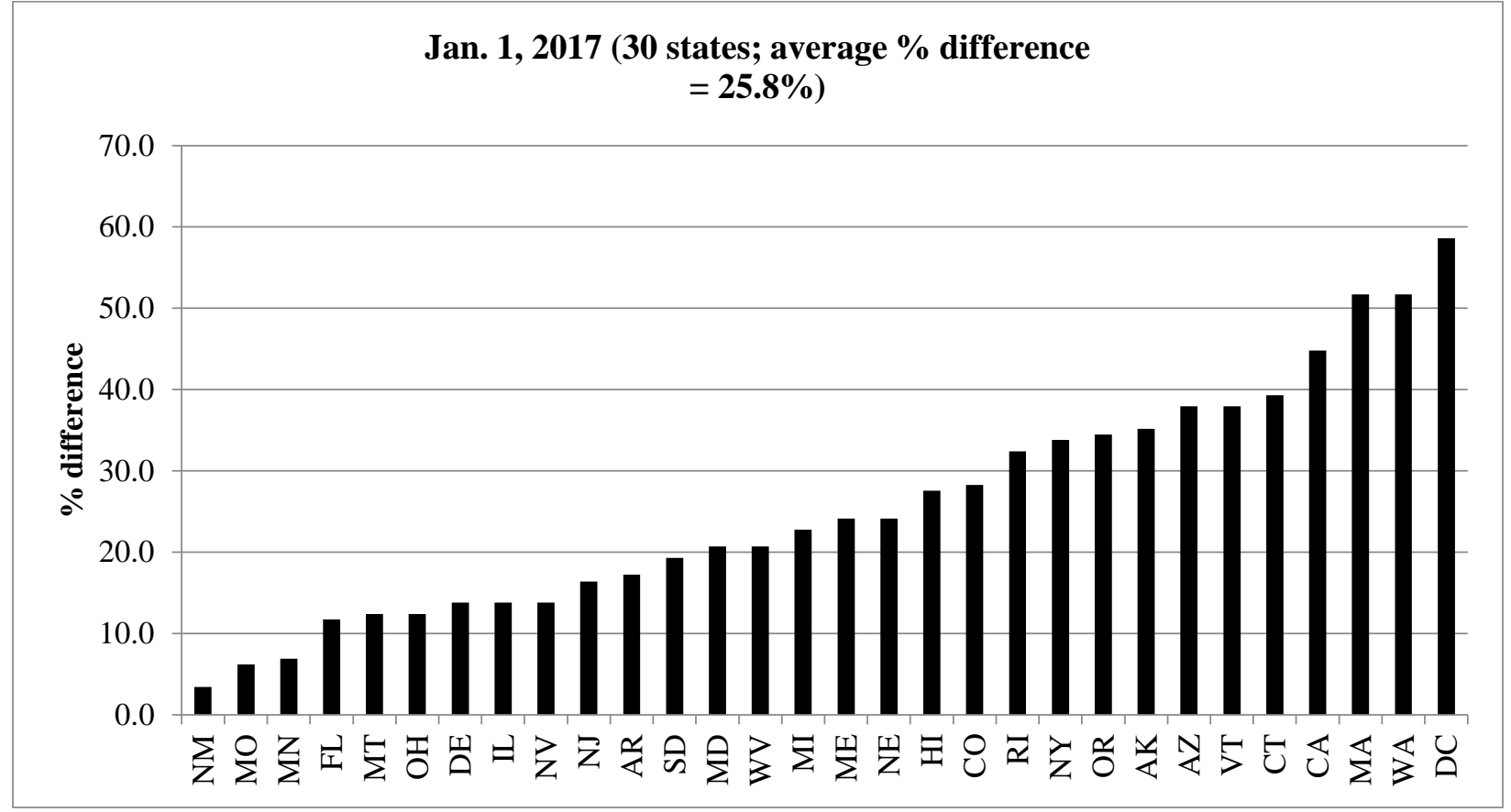


Table 1: Recent Estimates of Minimum Wage Effects on Unskilled Employment

\begin{tabular}{|c|c|c|}
\hline Authors & Employment elasticity and groups studied & Data/approach \\
\hline \multicolumn{3}{|c|}{ Geographically-proximate designs } \\
\hline $\begin{array}{l}\text { Dube, Lester, and } \\
\text { Reich (2010) }\end{array}$ & Near zero for teens and restaurant workers & $\begin{array}{c}\text { Paired counties on opposite sides of state } \\
\text { borders }\end{array}$ \\
\hline $\begin{array}{l}\text { Allegretto, Dube, } \\
\text { and Reich (2011) }\end{array}$ & Near zero for teens & $\begin{array}{l}\text { States compared only to those in same } \\
\text { Census division }\end{array}$ \\
\hline $\begin{array}{c}\text { Gittings and } \\
\text { Schmutte (2016) }\end{array}$ & $\begin{array}{l}\text { Near zero for teens; larger negative elasticities in } \\
\text { markets with short non-employment durations }(-0.1 \text { to } \\
-0.98) \text { and smaller positive elasticities in markets with } \\
\text { long non-employment durations ( } 0.2 \text { to } 0.46)\end{array}$ & $\begin{array}{l}\text { States compared only to those in same } \\
\text { Census division }\end{array}$ \\
\hline $\begin{array}{l}\text { Addison et al. } \\
\text { (2013) }\end{array}$ & $\begin{array}{c}\text { Varying sign, more negative, generally insignificant for } \\
\text { restaurant workers and teens; stronger negative at } \\
\text { height of Great Recession }(-0.34)\end{array}$ & $\begin{array}{l}\text { Similar methods to Dube et al. (2010) and } \\
\text { Allegretto et al. (2011) restricted to 2005- } \\
10 \text { period }\end{array}$ \\
\hline Slichter (2016) & -0.04 (teens) & $\begin{array}{l}\text { Comparisons to bordering counties and } \\
\text { other nearby counties }\end{array}$ \\
\hline Liu et al. (2016) & -0.17 (14-18 year-olds) & $\begin{array}{l}\text { Comparisons within BEA Economic } \\
\text { Areas (EA) that cross state lines, with } \\
\text { controls for EA-specific shocks } \\
\end{array}$ \\
\hline \multicolumn{3}{|l|}{ Other approaches } \\
\hline $\begin{array}{l}\text { Neumark et al. } \\
\text { (2014a, 2014b) }\end{array}$ & $\begin{array}{c}-0.14 /-0.15 \text { for teens, }-0.05 /-0.06 \text { for restaurant } \\
\text { workers }\end{array}$ & $\begin{array}{c}\text { States compared to data-driven choice of } \\
\text { controls (synthetic control), and state } \\
\text { panel data }\end{array}$ \\
\hline Powell (2016) & -0.44 for teens & $\begin{array}{l}\text { States compared to data-driven choice of } \\
\text { controls (synthetic controls, estimated } \\
\text { simultaneously with employment effect) }\end{array}$ \\
\hline Totty (2015) & $\begin{array}{l}-0.01 \text { to }-0.04 \text { for restaurant workers; }-0.04 \text { to }-0.7 \text { for } \\
\text { teens }\end{array}$ & $\begin{array}{c}\text { States compared to data-driven choice of } \\
\text { controls (factor model) }\end{array}$ \\
\hline $\begin{array}{c}\text { Dube and } \\
\text { Zipperer (2015) }\end{array}$ & -0.051 (mean) and -0.058 (median) for teens & $\begin{array}{l}\text { States compared to data-driven choice of } \\
\text { controls (synthetic control) }\end{array}$ \\
\hline $\begin{array}{c}\text { Baskaya and } \\
\text { Rubinstein (2015) }\end{array}$ & -0.3 to -0.5 for teens & $\begin{array}{c}\text { States, using federally-induced variation } \\
\text { as instrumental variable }\end{array}$ \\
\hline $\begin{array}{l}\text { Clemens and } \\
\text { Wither (2014) }\end{array}$ & $\begin{array}{c}\text { Appx. }-0.97, \text { for those directly affected by minimum } \\
\text { wage increase }\end{array}$ & $\begin{array}{l}\text { Targeted/affected workers versus other } \\
\text { low-wage workers in states affected by } \\
\text { federal increases }\end{array}$ \\
\hline Thompson (2009) & -0.3 (for teen employment share) & $\begin{array}{l}\text { Low-wage counties vs. higher-wage } \\
\text { counties in states }\end{array}$ \\
\hline
\end{tabular}

Notes: The table reports my best attempts to identify the authors' preferred estimates reported in the papers. The Thompson estimate cannot be compared directly to other elasticity estimates, because there is no population count in the data source used. The Clemens/Wither elasticity is based on a 6.6 percentage point decline (p. 27), divided by a 70.2 percent employment rate (or a 9.4 percent employment decline), divided by a $9.7 \%$ MW increase (50 cents, from p. 14, divided by $\$ 5.15$ ). (These numbers are reported in a 2016 version of the study.)

Source: Neumark and Wascher (2017, http://journals.sagepub.com/doi/abs/10.1177/0019793917698429).

\footnotetext{
${ }^{1}$ I am grateful to William Wascher for helpful comments.

${ }^{2}$ See Neumark and Wascher (2008, Chapter 2) for a review of some of the earliest evidence comparing effects for different workers after Oregon enacted a minimum wage for women (Obenauer and von der Nienburg, 1915), and comparing changes in manufacturing firms upon adoption of the minimum wage in the lower-wage South and the higher-wage North (Douty, 1941; Hinrichs, 1940; and Moloney, 1942), and debates about this evidence.
} 
${ }^{3}$ See Allegretto et al. (2017) and Neumark and Wascher (2017) for discussions of the most recent work on employment effects.

${ }^{4}$ See, in particular, Brown et al. (1982), Card and Krueger (1995), and Neumark and Wascher (2007, 2008).

${ }^{5}$ For recent discussions of my views on recent prior research, see Neumark (2016), Neumark et al. (2014a, 2014b), and Neumark and Wascher (2017).

${ }^{6}$ There are also many studies of the effects of minimum wages on other outcomes, such as poverty, training, and prices. My review does not cover these studies, but, naturally, many of the issues I discuss regarding estimating effects of minimum wages on employment carry over to studies of other outcomes.

${ }^{7}$ While this essay is not a survey, and focuses on U.S. evidence, the reader interested in evidence from other countries can see the earlier survey in Neumark and Wascher (2007). Some newer work for European countries, where within-country variation is typically non-existent, exploits changes in minimum wages at particular ages, in regression-discontinuity types of analyses (see, e.g., Yannelis, 2014, and Kreiner et al., 2017).

${ }^{8}$ For example, California, New York State, Seattle, and Washington, DC have scheduled (or have already reached) a \$15 minimum wage.

${ }^{9}$ Their approach parallels Card and Krueger (1994), although the two more recent studies provide a contrast between the results using different identification strategies. Other studies that use close controls in a similar fashion to Allegretto et al. (2011) find, not surprisingly, similar results (Addison et al., 2013; Gittings and Schmutte, 2016; and Slichter, 2016).

(Addison et al. do find stronger evidence of disemployment effects for teens during the Great Recession.) An exception is Liu et al. (2016), who estimate a county-level fixed-effects model that includes interactions between dummy variables for each quarter and BEA "Economic Areas," which are supposed to delineate regionally-integrated markets. Because some of these economic areas cross state lines, minimum wage effects can be identified from state variation within them. Liu et al. find evidence of disemployment effects for the youngest group covered in their data (14-18 year-olds), which are diminished only slightly - to an elasticity of - 0.17 - within Economic Areas.

${ }^{10}$ See the response to this research in Allegretto et al. (2017).

${ }^{13}$ Foreshadowing the discussion below, the magnitude is likely larger than other studies because it is calculated for a more directly-targeted group of workers (compared to teenagers or restaurant workers, only some of whom are directly affected by the minimum wage). Indeed, the elasticity is smaller when using a treatment group that includes higher-wage workers and hence is "less intensively" treated.

${ }^{15}$ See Allegretto et al. (2011, 2017), Neumark et al. (2014a), and Neumark and Wascher (2017).

${ }^{18}$ How minimum wages affect employment growth has not been a common question in past research on the employment effects of minimum wages. However, recent models using a "putty-clay" approach to technology have suggested that it might be useful to think about minimum wages having small initial effects on employment but increasing effects over time, as new technology comes on line that uses less low-skilled labor (e.g., Sorkin, 2015).

${ }^{19}$ See, e.g., Allegretto et al. (2011), who refer to unmeasured changes in technology leading to teens experiencing increased competition from adults for low-skilled jobs.

${ }^{20}$ A second model introduced the three regimes in the textbook "company town" monopsony model - the marginal cost of labor curve, the labor supply curve, and the labor demand curve, and actually found some evidence that the monopsony model fits the data better - although the textbook monopsony model is a far less plausible depiction of labor markets than more modern monopsony models that come out of search models (Manning, 2005).

${ }^{21}$ The original Kaitz index (Kaitz, 1970) also took account of coverage, which is not considered an issue in more recent decades when coverage became near universal.

${ }^{22}$ This is explored further in Aaronson et al. (forthcoming).

${ }^{23}$ See http://www.ncsl.org/research/labor-and-employment/state-minimum-wage-chart.aspx (viewed October 25, 2017).

${ }^{24}$ Reich and his co-authors take a particular stand, noting that their model is calibrated to "be consistent with the very small effects that researchers find for the smaller pre-2015 increases in federal and state minimum wages” (Reich et al., 2016, p. 20). This, of course, is their interpretation of the evidence, based on studies that Reich and his co-authors have done (in particular, Allegretto et al., 2011, and Dube et al., 2010). Perhaps not surprisingly, this leads them typically to project trivial effects of increasing minimum wages to $\$ 15$.

${ }^{27}$ See the summary in Neumark and Wascher (2017).

${ }^{28}$ For example, in 2016, teens were nearly 21 percent of workers paid hourly whose wages were at or below the federal minimum wage, but less than 6 percent of the total of workers paid hourly. (See

https://www.bls.gov/opub/reports/minimum-wage/2016/home.htm, viewed May 10, 2017.) The representation of teens among minimum wage workers would, of course, decline at much higher minimum wages, and is likely to be lower in states with higher minimum wages. 
${ }^{29}$ More recent research has turned to other potentially low-wage, low-skill groups, such as restaurant workers, in part because of using data reported by industry but not by age group (e.g., Dube et al., 2010).

${ }^{30}$ See Choi and Fernández-Blanco (2016).

${ }^{31}$ Like with the general literature on employment effects, there is conflicting evidence on whether or not the relative magnitudes of these two effects lead, on net, to employment declines - although there is no reason to use data on flows to estimate net employment effects of minimum wages.

${ }^{32}$ Still, a potential difficulty in predicting such effects is that the impacts on affected workers may also depend on the share of workers affected, as we might anticipate that firms find it easier to make adjustments along margins other than employment - such as benefits, training, customer service, prices, etc. - for small changes in minimum wages than for large changes in minimum wages. Put differently, there can be nonlinear effects of the share affected by minimum wage increases.

${ }^{33}$ For example, Monras (2015) presents some evidence of negative employment effects on the share of employment or fulltime employment among those with a high school degree or less, without regard to age. (This is apparent only from detrended estimates, using a method described earlier.)

${ }^{34}$ See Jardim et al. (2017).

35 The estimated elasticity from the usual minimum wage study will tend to understate the elasticity of demand for affected workers for a second reason. Because some affected workers are already earning more than the old minimum wage (but less than the new minimum wage), the size of the average wage increase associated with a higher minimum wage will be smaller than the minimum wage increase itself. Letting $\Delta W^{A}$ denote the average wage change of those workers whose wages are directly affected by the change in the minimum wage, and $\Delta M W$ the legislated increase, the demand elasticity for affected workers (that is, the elasticity with respect to the induced change in their wage) can be written as:

$$
e^{A}=\left(e / p^{A}\right) /\left(\Delta W^{A} / \Delta M W\right),
$$

where $\left(\Delta W^{A} / \Delta M W\right)<1$.

${ }^{36}$ Living wages were a policy that arose in many cities (and other local jurisdictions) in the United States in the mid-1990s. Living wages typically imposed wage floors much higher than minimum wages, but limited to much narrower sets of workers (city contractors, and firm receiving financial assistance from cities). For details and recent evidence, see Neumark et al. (2012).

${ }^{37}$ Neumark and Wascher (2008, Chapter 4) review the broader evidence.

${ }^{38}$ The more general question of differences in the effects of minimum wages on employment in the short-run versus the longer-run is of independent interest, aside from the validity of search models - as noted earlier with regard to Sorkin (2015) and Meer and West (2016).

${ }^{39}$ This same question can, of course, be applied to other topics on which there is a large research literature with conflicting evidence.

${ }^{40}$ For an example of an analysis focused on explaining variation in estimates, in a different context (the returns to schooling), see Ashenfelter et al. (1999).

${ }^{42}$ Another issue taken up in meta-analyses is publication bias in the published literature on minimum wages. However, it is very hard to distinguish between publication bias and other sources of patterns in the published evidence consistent with publication bias. For example, meta-analyses like Doucouliagos and Stanley argue that if negative estimates of minimum wage effects have larger standard errors, this is evidence of publication bias in favor of studies finding negative effects. However, the same phenomenon can arise if studies using better research designs lead to "truer" estimates, which happen to be negative, and which have larger standard errors because they demand more of the data.

${ }^{43}$ For an initial attempt at this, see Shirley (2017).

${ }^{44}$ Another example not discussed thus far is how different labor market institutions influence the employment effects of minimum wages (Neumark and Wascher, 2004; Addison and Ozturk, 2012). 